\title{
Performance and intentionality when considering expectations, agreements and practices to write essays in a high school Mexican context
}

\begin{abstract}
This research presents the characterization of teenager students' performances when writing essays in Spanish in activities to consider expectations and agreements about this textual genre in high school context in Mexico City. It also contemplates feedbacked revision and edition practices to try to achieve an improved version. Methodology includes an exploratory survey on knowledges related to this genre, recognition and discussion of different types of essays, and textual modification strategies, according to agreements reached upon expectations of essays in high school. The descriptive methodology includes criteria and expectations of textuality, discursive resources of essays and intentionality in writing. Results show lack of correspondence between expectations about essays and written practices. Agreements reached and feedback favored partial advancement in performance, which corresponded to intended essay writing, in terms of criteria of informativity, intertextuality, coherence and adequacy. This research provides reflexive relationship between expectations about essay textual genre, writing and editing practices, as well as methodological and descriptive procedures to study performance and intentionality in written practices.
\end{abstract}

Volume 3 Issue I - 2019

\author{
Ernesto Hernández Rodríguez \\ Doctor in Linguistics, Universidad Nacional Autónoma de \\ México, Mexico
}

\begin{abstract}
Correspondence: Ernesto Hernández Rodríguez, Doctor in Linguistics, Universidad Nacionall Autónoma de México, Emiliano Zapata 18, Guadalupe Victoria Cuautepec, 07209. Ciudad de México, México, Tel 0445527454505 , Email ernestotem@live.com.mx
\end{abstract}

Received: December 21, 2018 | Published: January 16, 2019

Keywords: essay, high school, textual genre, intentionality, textuality

\section{Introduction}

Writing scholar essays is controversial because of different conceptions of this textual genre in each context, its characteristics, different approaches in academic perspectives and written practices. Students need to solve formal structuring, content, knowledge, organization of ideas, opinions, critical positions and written expectations in different classes. It is essential to determine the objectives and cases in which writing essays in high school is justified. Given the diversity of essays, it is ideal to reach agreements with students about the characteristics of this textual genre in specific situations in school communication. The existence of a variety of considerations to write essays favors the difficulty for its characterization. In school context, these texts involve multiple criteria of writing, textual resources and practices of academic socialization. Essays have been studied in the perspectives of school writing ${ }^{1,2}$ and textual conceptions of teachers ${ }^{3}$ and students. ${ }^{4-6}$

This research presents a study of performance and intentionality of high school students in writing, revision, editing and feedback on expectations and agreements reached to write essays in Spanish in a Mexican literature course. The first part presents the objectives, theoretical considerations and discussions about essays in scholar context. The article continues with a characterization of participating students and criteria on essay textual genre. The methodological section involves students' considerations and knowledges about essay genre. It includes activities for identification, revision and discussion of different types of essays, agreements reached on the characteristics of the essay in the literature course, with the idea of achieving an improved version. Textual description contemplates categories about textuality, type of text and intentionality when regulating performance through experimentation of writing strategies.

The purpose of this research is to characterize descriptively the written performance of high school students and their expectations to write school essays in Spanish, as a result of an educational experience to encourage taking agreements, revision and editing in a Mexican literature course in high school. This study is worth trying to provide feedback practices in writing, as well as to reflect and make agreements on essay expectations in different classes, given the diversity of criteria on this textual genre in a variety of disciplinary and school contexts.

\section{Theoretical considerations}

\section{Intentionality and textuality in scholar essays}

Students' considerations about essay genre and its writing ${ }^{4-6}$ show multiple criteria, experiences and knowledges about these texts in school situations. Morever teachers have different ways of conceiving essays and criteria to write and evaluate them. The possibility of agreeing with students the characteristics of these writings in each subject, allows critical reflection on textual essay genre. Therefore, this research emphasizes interactions to reach agreements on essay writing expectations. Assessment of intentionality in management of essay textual genre, allows us to appreciate what the author tried to express, ${ }^{7}$ attempts to improve writing through compensatory strategies $^{8,51}$ and performance regulation ${ }^{9,54}$ when trying to follow agreements reached to write essays. Criteria and expectations about essays provide resources to establish descriptive categories in writing and modifications made by students.

De Beugrande \& Dressler (1997) textual standards proposal allows the characterization of texts through the criteria of informativity (type of content), situationality (context), adequacy (relevance) and intentionality (attitude to try to express a message). Textual genre involves form and function in a certain context. Likewise, intentionality in writing is manifested in textual representation of author and interlocutors. ${ }^{10,11}$ Studies about complexities to determine textual genres ${ }^{12}$ provide background to consider formal and 
functional criteria in a variety of texts. Research on different textual genre perspectives has also emerged: multiplicity of text types, ${ }^{13}$ social, situational and discursive manifestations in writing ${ }^{14}$ and characterization of contexts. ${ }^{15,16} \mathrm{We}$ can find a variety of essay styles and criteria, for example, in divulgation of science, literature, politics, philosophy and history. So, it is inappropriate to propose rigid and unique models about this genre. It is relevant to become aware of modalities of these writings and scholar practices of socialization to write them in certain school situations. At times, these criteria respond to various academic and school traditions. ${ }^{17}$ The following section presents an overview of different conceptions about essays, however, the focus of interest is scholar enviroment.

\section{Concepts about essay genre in school environment}

Studies on essays have been addressed in theoretical perspectives ${ }^{18-20}$ and in studies of textual genre. ${ }^{21-24}$ We can find historical and panoramic reviews about this genre. ${ }^{25-28}$ Mainly, there is controversy to characterize it in school environment. ${ }^{29,30}$ Michel de Montaigne (2006) called his reflective writings Essais with formal and thematic freedom on various issues. ${ }^{50}$ Subsequently, essay genre was adopted in different areas of knowledge and writing traditions. At school, essays coexist and, at times, are confused, mainly, with research reports and critical reviews. Decontextualized incorporation of multiple writing traditions has produced confusions about the characteristics of these texts in school environment. Essay genre has been considered as "a literary composition usually brief about a specific subject, which often deals with a topic from a personal point of view"1, ${ }^{31}$ or a "literary prose genre, of didactic character based on reflections on philosophical, artistic, historical subjects, etc." ${ }^{32}$ For Hidalgo-Capitán (2012) an essay is:

"a literary genre in prose, dealing with philosophical, artistic, literary, historical, social, economic, political, etc., with a didactic character. [...] Thus, an essay is a composition written in prose in which an author exposes personal interpretations on a subject or, more precisely, in which an author develops his ideas, without needing to show a scientific methodological structuration for the sake of greater readability and explanatory capacity" (p.11) ${ }^{3} .48$

The literary approach fosters controversial expectations. We can ask ourselves: Do high school students express a literary style in their essays? And what are the resources that need to be mastered? The Royal Spanish Academy (RAE) eliminates the literary criteria and considers that an essay is a "text, usually brief, consisting of thoughts of the author, on a subject, without the apparatus or the extension that requires a complete treatise on the same subject." (RAE, 2001: 925) ${ }^{4}{ }^{52}$ Rojas Román (2011) reduces the literary aspect by stating that:

"The essay always has the scientific part because it relates the facts and the subjective or literary part to have the critical judgment of the essayist. The essay, then, is not an innovation of a theme but a construction based on the experience that the essayist has taken from his reality, then, it is a particular way of expressing something" (p.2) ${ }^{3}$.

In fact, an essay is not a scientific text or a research report with the

${ }^{1}$ Original quotation $(\mathbf{O Q})$ : "una composición literaria usualmente breve acerca de algún tema específico, que muchas veces trata el asunto desde un punto de vista personal" (Gómez de Silva, 2004: 256). ${ }^{31}$

${ }^{2} \mathrm{OQ}$ : "género literario en prosa, de carácter didáctico basado en reflexiones sobre temas filosóficos, artísticos, históricos, etc." (Larousse 2015: 289).

${ }^{3} \mathrm{OQ}$ : "El ensayo siempre cuenta con la parte científica porque relaciona los hechos y la parte subjetiva o literaria por contar con el juicio crítico de ensayista. El ensayo, entonces no es una innovación de un tema sino una construcción en base a la experiencia que el ensayista ha tomado de su realidad, entonces, es una forma particular de expresar algo." (p. 2). characteristics of the experimental method of science. In this textual genre, the term hypothesis is only a preliminary statement or thesis to be developed and not a question to be solved in conclusions. García Córdoba \& González Méndez (2014) point out that

"The essay always has the scientific part because it relates the facts and the subjective or literary part to have the critical judgment of the essayist. The essay, then, is not an innovation of a theme but a construction based on the experience that the essayist has taken from his reality, then, it is a particular way of expressing something" (p. 2$)^{5} .^{53}$

In some logical and argumentative proposals, an essay is a text to assume a position, for or against, on a given topic, using arguments and premises to reach a conclusion or try to demonstrate a position. ${ }^{33}$ However, in most essays, the goal is free reflection. Thus, we do not find logical and argumentative resources in predominantly descriptive and expository essays to present knowledge or approaches, for example, in the panoramic perspective of Reyes ${ }^{36}$ in the Valley of Anahuac, in emotional, sentimental or amorous topics ${ }^{34}$ and in very personal assessments, for example, on the character of Mexicans. ${ }^{35}$ In these cases, the subjective style predominates. In fact, an argumentative characterization would be really controversial.

Moreno, Marthe and Rebolledo (2010) take into account performance of students, who are not expert writers, and, in fact, face essay writing complexities for the first time. In addition, they discard the literary consideration and highlight subjectivity and thematic freedom, eliminating scientific rigor, considering that an essay

"consists of the arguments and the main or substantive affirmation that we wish to present. Such a claim is called preliminary thesis or, more adequate, hypothesis. This is because it can not be sustained or demonstrated with the solid argument that a thesis requires." (p. 32) .

To enrich this proposal, I believe that essay writing requires a creative style with formal freedom for dissemination of knowledge, and without the need for a scientific and methodological structuring. In a school essay, the expectation of argumentation is focused on attracting the attention of the reader to convince him about the points of view and contents presented. The purpose is dissemination and exposure of knowledge, without pretending to prove or conclude positions. In this way, argumentative and expository discursive resources are involved in this type of essay.

Numerous expert authors assume that readers have complete knowledge of the topic, and therefore omit bibliographical references, for example, $\mathrm{Paz}^{35}$ and Reyes ${ }^{36}$. However, according to adequacy and situationality criteria, ${ }^{37}$ a high school essay mainly fulfills the function of knowledge divulgation. It is important to remember that teenageer students are not experts. In fact, they need to gather information and investigate what they try to communicate to a scholar audience, which also needs information about contents. Therefore, in this research students were asked to present bibliographic references, since their interlocutors interacted in scholar context.Thus, students could anticipate and assume the characteristics of their interlocutors in a specific reading context. ${ }^{38}$

\section{About students and essay tradition in Escuela Nacional Preparatoria in Mexico City}

In this study, 37 teenager students from National Preparatory

${ }^{4} \mathrm{OQ}$ : "consta de los argumentos y la afirmación principal o sustantiva que se desea presentar. Tal afirmación se denomina tesis preliminar o, más adecuado, hipótesis. Esto en razón de que no se puede sustentar o demostrar con la solidez argumental que una tesis requiere." (p. 32). 
School in Mexico City participated. They were studying the Mexican and Latin American Literature course in the third school year in October 2016. Previously, these students wrote summaries and monographs. They read essays in the Spanish Language course and reviews in the Universal Literature one. The third course included essay writing about literary trends, readings and authors in their historical context: "By writing essays students will develop the critical and sustained expression of their views on a topic of personal interest to the course" ${ }^{4}{ }^{47}$ The program does not indicate the characteristics of the expected essay; the teacher has to determine the criteria, so there is the possibility to negotiate with students on the essay characteristics. Therefore, the idea was to socialize with the students different types of essays, in order to get acquainted with multiple expectations about this textual genre.

\section{Teaching methodology and elicitation}

In the course, we had addressed pre-Hispanic literature, chronicles of the conquest, colonial texts and writing of summaries and comments of the readings. As a preliminary phase to writing, students read the text or texts they chose and made an oral report. Subsequently, they identified and selected information on a subject of the course. I asked them the following questions in order to help them determine the essay theme:

On what topic of the course would you like to write your opinions and reflections?

Why are you interested in this topic?

What readings from the course are you interested in?

What information do you have or have you researched on this topic?

In the following three sessions, the students received oral and individual feedback to clarify the readings and information on the subject. In the next session, they answered what they knew about essay genre:

\section{What is an essay?}

\section{List 5 characteristics of an essay}

Open answers allowed manifestations of diverse conceptions and expectations. I commented that in an essay the author reflects on some topic. I told them that there are different ways to write it, and that we would have to reach agreements for its writing in our course. Afterwards, during two classes we read and discussed different types of essays in groups to have a panoramic view of their different modalities. I selected representative essays from different writing styles and traditions, mostly on Mexican literature. ${ }^{39-41}$ Appendix 1 presents the titles of these essays and a brief explanation of their characteristics. We began the reading activity of each essay in class; students continued at home. For the most complex essays, ${ }^{40-41}$ I presented the contents and the textual characteristics, I read some passages and we discussed them. Then, we emphasized the characteristics of the reviewed essays. The purpose was to become aware of the diversity of these writings, and thus contemplate the importance to reach agreements about essay characteristics in our course. In a brainstorming session about expectations of school essays, the students prioritized their points of view, and exposed what they investigated. For the most part, they said that it was not necessary to use a critical structuring or bibliographical references. They confused essays with summaries and reviews. Then, I proposed considering the characteristics of essay genre, previously presented, by Moreno et al., ${ }^{42}$ (2010: 49). Finally, we agreed on the following criteria:

"In the Mexican literature course, an essay corresponds to a reflection with a subjective and free interpretation on a given topic to express approaches, without determining firm solutions or a research development. It requires a creative style and formal freedom to spread knowledge and, mainly, the point of view of the author. In order to share information to a general public, it is necessary to include the sources of the research, citations and bibliographical references"s. (Agreements reached with the students)

In the next phase, they organized the contents in 2 cards for the readings and 2 for the selected theme. The purpose was to determine the essay contents. I told them that the information they investigated was useful for their selected topics of interest, with the idea of sharing knowledge and opinions to a non-expert public on the subject.

\section{Readings}

Selected readings of the course

Explanation or point of interest

Opinion or interpretation

Sources consulted

\section{Topic}

\section{What I investigated}

Explanation or point of interest of the investigation

Opinion or interpretation

Sources consulted

In the next sessions, I guided students to clearly express the essay title, contents, purposes, free points of view, readings from the course, sources of consultation and a bibliography in any format. They wrote the first version, and then received written and oral observations and suggestions, based on the agreements that we reached together. This perspective of interactive guidance and dialogical feedback favors revision and reflexive modification of their texts. ${ }^{43,44}$ These type of interactive consultancies constitute the teaching methodology, and the elitictation practices involved, that is, the techniques and procedures that allow access to representative samples of written performance, for subsequent descriptive analysis. ${ }^{45}$ In order to try to write an improved second versión, I explained the students how to solve main difficulties: incorporating information and exemplification with readings and opinions. I insisted on considering the agreements reached to modify and improve writings. Finally, they accomplished the second version during the next three sessions.

\section{Results and discussion}

\section{Considerations of the students about essay characteristics}

Results of the initial students' considerations of essays characteristics exhibit different criteria for this textual genre. In

${ }^{5} \mathrm{OQ}$ : En el curso de literatura mexicana el ensayo corresponde a una reflexión con una interpretación subjetiva y libre sobre un tema determinado para expresar planteamientos, sin determinar soluciones firmes ni un desarrollo de investigación. Requiere de un estilo creativo y de libertad formal para difundir un conocimiento y, principalmente, el punto de vista del autor. Con el propósito de compartir la información a un público en general, es necesario incluir las fuentes de lo investigado, citas y referencias bibliográficas. 
the majority of the 37 students' conceptions, the idea that an essay exposes a topic or points of view predominated. In this way, 17 students considered opinions: about their own ideas (6) or about those of the author of the selected readings (6), about a literary text and its characteristics (4), about a certain topic (2) or one they investigated (4), or as an argumentative text (3). On the other hand, 9 students contemplated expository criteria, considering that an essay is a writing to "talk" about a topic (7). On the essay conception as a text of analysis (6 students), 4 posed the descriptive resource, one the subjective opinion and another the expression of ideas with "not so specific" arguments. In addition, 4 students expressed that an essay "is a synthesis" and another 4 a report: of reading comprehension (2) and of opinion with summary "that chronologically explains the story and gives an opinion" (2). On the other hand, 2 students considered an essay as a story with opinion, 2 as a literary genre, one as a free text "of any kind" and 3 omitted this information.

Likewise, results exhibit the following criteria: 13 students considered a structure that included introduction, development and closure, 7 the presentation of a specific topic, 5 students were interested in handling true and supported information, 4 focused on formal language and, on the other hand, 3 considered simple direct writing without complications, 3 an objective approach, 3 a subjective one and 2 an analytical. Four students mentioned author quotations, 4 bibliography, 3 considered descriptions of characters and 2 exemplification to support ideas. The following aspects were mentioned on one occasion: objectives, research purposes, methodology, opinions from other authors, sharing information of a topic, recommendations, originality, improvisation at times and variable length.

Pre-writing practices show difficulties to systematize information from the selected readings and investigated information about a topic, students' points of view, interpretations and management of bibliographic sources. In addition, 9 students experienced difficulties to express their interests on a topic of the course and relating it to the readings or to some general knowledge or previous courses. Also, 14 students said they did not have any information about the selected topic. For the most part, we observed difficulties in identifying and relating information from the course texts and what was investigated on the subject. Therefore, emphasis in counseling was to achieve accuracy in information and purposes of scholar essay.

\section{Criteria on essay expectations in the drafted versions}

The students contemplated different criteria of textuality, related to writing in a free structuring or in the classical form (introduction, development, closure), management of contents of the readings and information investigated on the subject (informativeness), either in an expository or commented way, by mentioning points of view or even trying to develop them in writing. We observe different uses of consultation sources, for example, with textual citations and bibliographical references (intertextuality). Students' written performances exhibit attempts to share knowledge with appropriate language according to school context (adequacy and situationality). In some cases, students represented themselves textually to provide their opinions and they also involved interlocutors. As a result of feedback, they contemplated the agreements reached about essay expectations for the course.

We can appreciate partial progress in written performance in the drafted versions. None of the students used the research report model or argumentation with hypotheses to demonstrate a position and conclude. Free expression of ideas predominated: 29 of 37 in both versions. Those who preffered the classical structure (introduction, development and closure), tried to start with information about contents from the course readings and what they investigated about the topic to enrich the essay. However, difficulties to organize ideas predominated, since, sometimes the sections included did not really correspond to introduction, development and closure functions. Therefore, the purpose in feedback interaction was to properly handle information throughout essays.

Table 1 shows the categories to characterize difficulties faced, drafting decisions to use contents of the course readings, investigation on the subject and opinions. In each category, we observe the number of occurrences, that is, the occasions when a specific resource or textual practice is presented in the writings. Management of contents corresponded to informativity standards (De Beugrande \& Dressler, 1997) and expression of points of view in students' textual representations as authors. ${ }^{10}$ Characterization of textual performance allows contemplating intentionality (Beuchot, 2015) in the attempts to follow agreements reached about essay characteristics. Data show different types of progress in performances, as a result of revision and edition in counseling to improve writing in a second version.

Results show that students written performances did not correspond with their considerations about essay characteristics in the initial questionnaire, where, mostly, they highlighted the idea that this genre is used to comment and analyze a topic. The preference for exposing information investigated in both versions evidences difficulties in managing and understanding the readings of the course. This performance also exhibits the predominat conception of essays as texts to share knowledge from sources of consultation. Likewise, difficulties, partial progress in content management of the course readings $(17,23)$ and reduction of those who presented contents on what was investigated in the second version $(34,31)$ evidence complications related to informativity textual standard. We can appreciate student's difficulties to represent themselves as authors and express points of view $(10,17)$. Interaction to provide feedback was useful in written performance since there was no increase in the number of those who only expressed their points of view without trying to develop them $(9,9)$, and favored partial advance in the attempts to comment $(10,17)$ and to share knowledge through explanations or exemplifications $(9,17)$. In this way, partial advance in performance prevailed, corresponding to texts with essay intentionality expression.

In the agreements reached, we considered expressing opinions and sharing knowledge in school context, that is, to a non-expert public in the subject. For this purpose, it was essential to try author textual representation and taking readers directly into account. ${ }^{10}$ Among those who achieved this type of representation $(20,28)$, we can appreciate a remarkable progress in essays of those who, in the second version, in addition, tried to divulgate knowledge by means of these textual representations (11 of 28 : texts $3,4,6,9,13,19,20,27,35,36$, 37). Also, it is noticeable the partial progress of those who in the first version tried to share information, but presented difficulties to comment contents. In this way, students had to solve, in an integral manner, textual criteria related to contents, points of view and textual representation, as characteristics of the agreements reached for the expected essay in the course.

About written practices of intertextuality (De Beugrande \& Dressler, 1997) to relate sources of consultation, citations, textual references and bibliography, Table 2 shows an initial tendency to use these strategies in a reduced way to refer to the readings or 
the investigated information. Second versions exhibit a remarkable progress in intertextuality practices. Agreements reached and socialized involved writing with a purpose of sharing knowledge in school environment (situationality), with accessible language (adequacy) to a non-expert public (representation of interlocutors), and information about consulted sources (intertextuality).

On the other hand, written expected performance was not limited to achieving the corresponding textual genre and the discursive resources to expose and divulgate contents (informativeness) and expressing comments (representation of the author). In addition, it was essential to interrelate coherence and textual adequacy criteria in contents. Table 3 presents the classification of students' texts based on assessment of information in terms of pertinency or relevancy, related to coherence and adequacy. Coherence corresponds to clarity without ambiguities in contents from the course readings and those investigated in different sources. Adequacy is related to appropriate handling of information and language that corresponds to school context. For example, certain students presented pertinent investigated information for their essays, however, they also included contents, on the selected topic, that were alien to the readings of the course. In these cases, it was necessary to solve coherence and to achieve adequacy in school context
Coherence had to correspond to agreements reached and socialized in a suitable scholar context. Students faced difficulties to fully assess pertinence of the information related to topics addressed, selected readings and what was investigated. The initial tendency to present alien or deviated information manifests the problems to identify and select contents according to high school essay expectations.

In the second versions, we can appreciate a reduced progress in intentionality and performance in the attempts to present pertinent information related to the course readings $(18,24)$ and investigated contents $(17,21)$. This situation evidences the importance to support students when trying to determine and interrelate contents and objectives in their texts. Essay writing involved appropriate textual genre, elements of informativity and intertextuality, and assessing contents in terms of coherence and adequacy in high school context. Finally, only 17 of the 37 students could solve, in a comprehensive manner and following the agreements reached, essay expectations. In the other texts, we can observe partial progress. Therefore, students' performances predominatly reflected essay intented writing. In this situation, the purpose was to assess intentionality in the revision and textual edition process in the attempts to improve the second version.

Table I Informativity: expositions and comments

\begin{tabular}{lll}
\hline Criteria considered for essay genre & First version & Second version \\
\hline Exposition of contents from the course readings & (number of occurances) & (number of occurances) \\
Exposition of content from investigated information & 17 & 23 \\
Expression of points of view, without developing them & 34 & 31 \\
Attempts to develop points of view throughout the text & 9 & 9 \\
Attempts to share knowlege by explanation and exemplification & 9 & 17 \\
Direct representation as an author & 20 & 17 \\
\hline
\end{tabular}

Table 2 Intertextuality and references to sources consulted

\begin{tabular}{|c|c|c|}
\hline Criteria considered for essay genre & First version & Second version \\
\hline & (number of occurances) & (number of occurrences) \\
\hline References to authors or texts without bibliographic information & 8 & 4 \\
\hline Quotations or references to readings or investigated information & 12 & 22 \\
\hline Bibliographical references & 21 & 31 \\
\hline
\end{tabular}

Table 3 Qualitative assessment of content pertinence

\begin{tabular}{lll}
\hline Information about the course readings & First version & Second version \\
\hline Pertinent or relevant & 18 & 24 \\
Alien or deviated & 19 & 13 \\
Information investigated on the subject & First version & Second version \\
Pertinent or relevant & 17 & 21 \\
Alien or deviated & 20 & 16 \\
\hline
\end{tabular}

\section{Intentionality characterization in a representative text}

This section presents a representative written performance in fragments in both versions of a selected essay. Textual characterization contemplates integral consideration of agreements reached about essay expectations in the course. In order topresentwriting with greaterfidelity, transcription respects the text as it was written by the student, without corrections in spelling, accentuation, punctuation or segmentation of words. The same criteria applies to translations of these fragments into English, in which only contents are emphasized, without trying to organize or correct Spanish writng dificulties. In Appendix 2, we can 
read this representative text example (Text 20f) in both versions with its translations. The second version presents progress, for example, in content managment, opinions, sharing knowledge, author textual representation and intertextuality relationships to relate consulted sources. Regarding criteria of informativity, the student expressed interest in sharing knowledge about prehispanic god Quetzalcóatl in literature. She had to incorporate course readings, expand and relate investigated information. On intertextuality relationships, she needed to incorporate bibliographical references and to complete information from consulted sources. She managed to represent herself textually, for example, by expressing her purpose: "quiero dar a conocer" and by including herself with interlocutors in second person plural representation: "lo que conocemos como el México actual", "nuestros antepasados" and "podemos tomar un trozo". Her language and vocabulary performance was relevant (adequacy) to school context (situationality).

In her introduction, the student needed to incorporate the required contents (informativeness) about the essay purposes and the topics addressed, as well as to directly relate Quetzalcóatl's topic, for example, by means of quotations about consulted source (intertextuality). Therefore, feedback interaction emphasized these aspects and following the agreements reached. In her development of essay structure, the student shared information about Quetzalcóatl, with an adequate language for knowlege divulgation. In addition, she reflected to understand and assess the impact of Quetzalcóatl on culture. However, the text required interrelating contents of the course readings, what was investigated (informativity) and references to consulted sources (intertextuality).

In consultancy interaction it was fundamental to highlight the well-achieved aspects in the student's performance: relevance of the topic, reflection on Quetzalcóatl, author and interlocutors representations and language adequacy. Feedback focused on solving difficulties in incorporating relevant information and opinions. In the second version, the student decided not to modify the introduction. Therefore, regarding criteria and expectation of informativity, she did not advance in relation to her first introduction attempt. She was aware about the need to provide enough information about purposes, relationships with literary texts, importance of context and consulted sources, as well as to specify the fragment of Quetzalcóatl myth that she was interested to write about.

The student advanced in terms of information and intertextuality elements, incorporating pertinent content about course readings. She expressed her opinions on the subject. Regarding intertextuality, she reported on the fundamental source of her essay: Cantos y crónicas del México Antiguo (León-Portilla, 2003), however, she did not specify that the other consulted texts are included in this book. Likewise, she incorporated a bibliography, but did not include data of the cited source and presented other texts that she did not consider in her essay. She commented that she actually relied on all the readings to write her essay. Then, I reminded her that, according to agreements reached and socialized, the expectation was to share and divulgate information (adequacy and situationality), so she had to consider bibliographic sources and include them in the essay.

What the student considered a "conclusion" is actually a closure and a motivation to know and value Quetazlcóatl in literature and history. I commented her favorable performance aspects, fundamentally, adequacy of language and her textual representation and that of the readers, in second plural personal pronoun. I emphasized the importance to specify aspects of intertextuality, due to the confusion about the readings consulted and referred to, when stating that it is clear that Quetzalcóatl is mentioned in several books and readings. She had to clarify that she only focused on some texts from LeónPortilla's anthology (2003). ${ }^{49}$

\section{Conclusion}

The results allow us to highlight conclusions related to expectations and performances on textual genre, revision and edition of essays, as well as teaching methodology and management of categories to descriptively characterize essays. Regarding the considerations related to essays, the lack of correspondence between the initial expectations about essay genre to comment and divulgate knowledge, and, on the other hand, the predominantly expositive expression in the first versions, constitute manifestations of the need to interrelate textual conceptions, agreements reached and feedback to modify the texts. Therefore, it was not enough to have expectations and to be aware of the characteristics of school essays. In fact, it was essential to learn how to gradually handle textual strategies in the writing process. For example, considerations on structuring in introduction, development and closure did not correspond in practice with the organization throughout the texts, so feedback interaction was necessary to improve writings.

Due to the predominance of partial progress in performance, most of the writings presented essay intentionality on expectations and agreements reached and socialized in highschool context. In this situation, the purpose was to assess intentionality in the attempts to solve writing difficulties. This proposal to characterize intentionality in writing, revision and editing, can be applied and adapted in different school environments, with the purpose to consider expectations about essay genre, socialization of agreements reached together, practical written experiences and strategies to improve the second version.

The results on the criteria related to school essay, show different expectations, practices and progress in performance. The agreement socialized allow us to establish the expectation of a text to freely express ideas and reflections, even though in the initial version the expository resource predominated. Subsequently, the second versions were characterized by free structuring to try to express points of view and to share knowledge, through expository and opinion resources, with the support of bibliographic sources. These criteria are opposed to the traditions of attributing to essays the logical-argumentative model and the rigor of the report or research text, which is not suitable in this kind of high school written experience.

Students faced problems to solve, in an integral way, resources to handle contents of the readings and what they investigated, points of view, knowledge divulgation, textual representation as author and relations of intertextuality. Partial advance in performance evidences the importance to develop a gradual process in writing and to consider intentionality and textual decisions when modifying the essays. Awareness of agreements led to assessment of essay expectations and written practices.

Difficulties and partial advance in the handling of elements related to informative criteria in contents of the readings and investigated information, show that students needed to develop skills to select and value contents, as well as to use discursive resources in expositions and comments. By keeping in mind interlocutors and representing themselves textually as authors, students advanced in written comments. By considering adequacy expectation, they tried to divulgate accessible information to a non-expert public, with explanations, examples, consulted sources, citations and 
bibliographical references. In this way, students partially advanced in performance and intentionality. We can appreciate the interrelation of discursive resources to expose and comment, criteria and expectations of informativity (content management) and intertextuality (sources of consultation and bibliographical references). Determining pertinent information, in terms of coherence and adequacy, fostered the interrelation of objectives and contents in essays. Feedback facilitated awareness of school essay purposes and management of information, related to the topic and the readings of the course. Characterization of high school essay involves permanently consider expectations, agreements, textual practices, type of text, discursive resources, informativity and intertextuality criteria, as well as the contents in terms of coherence and adequacy in school context. Integral vision of these aspects may be useful in future research as an approach to descriptively characterize performance and intentionality in expectations, agreements and textual practices in high school essays.

The methodological contribution of the previous activities to the writing phase, favored reading comprehension, identification and selection of information and bibliographical sources. Students required help to determine what they wanted to write and investigate, as well as relevance of information when relating content and objectives. For this reason, it is inappropriate to request writing essays without a preliminary preparation phase. Reading different types of essays, and finally, agreeing on essay expectations in the course, allow recognition of different traditions and practices in contexts of academic socialization for this textual genre. Likewise, this propoosal allows to contemplate expectations and achievements in written performances. In addition, feedback through written and oral suggestions fosters dialogical interaction and performance regulation. This study shows that management of textuality categories favors the characterization of writing and textual genre.

Criteria of informativity, for the selected readings and the investigated information, and intertextuality, for the sources and bibliographical references, allow to relate contents and attempts to express them by means of comment and exposition resources. Author and interlocutors representation helps to present information and comments. Also, determining content pertinency and its relation to readings, investigated information and objectives, facilitated appreciation of the attempts to select information and its relation with the essay objective.

This research provides a panorama of different traditions about essays in scholar context in Mexico. This type of experience promotes reflection of teachers and students on this textual genre, which is really dynamic with multiple manifestation possibilities, and its socialization in a given course. In this way, students can be conscious of the importance to contemplate expectations, agreements and practices when writing essays in high school context, as well as assessment of their written intentionality.

\section{Acknowledgments}

None.

\section{Conflicts of interest}

The author declares there is no conflicts of interest.

\section{References}

1. Blanco Puentes, Juan Alberto. A la hora de escribir ensayos, Tabula Rasa. 2006;5:209-227.
2. Gasca Fernández, María Alejandra, Díaz Barriga Arceo, et al. Habilidades argumentativas en la producción del ensayo escolar. Una experiencia educativa con estudiantes mexicanos de bachillerato Perspectiva educacional Formación de profesores. 2016;55(1):73-93.

3. Rodríguez Ávila, Yildret del Carmen. El ensayo académico: algunos apuntes para su estudio, Sapiens. Revista Universitaria de Investigación. 2007a;8(1):147-159.

4. Rodríguez Ávila, Yildret del Carmen. El ensayo: una estrategia para la promoción de la escritura en el Instituto Pedagógico Rural Gervasio Rubio, Investigación y Postgrado. 2007b;22 (2):231-258.

5. Jarpa Azagra, Marcela, Salas Valdebenito, et al. Representaciones sociales del género académico ensayo en la licenciatura en historia, Boletín de Lingüística. 2011;23(35-36):81-100.

6. Vyncke, Michelle. The concept and practice of critical thinking in academic writing: an investigation of international students perceptions and writing experiences, London: King College London. 2012. p. 1-71.

7. Beuchot, Mauricio. Elementos esenciales de una hermenéutica analógica, Diánoia. 2015;60(74):127-145.

8. Oxford, Rebecca. Language learning strategies: what every teacher should know. Boston: Heinle \& Heinle Publisher. 1990.

9. Wenden, Annita. Helping language learners think about learning. In Rossner, et al., editors. ELT Journal. An international journal for teachers of English to speakers of other languages. 1986;40(1):161175.

10. Hyland, Ken. Metadiscourse: Exploring interaction in writing. London/ New York: Continuum. 2005.

11. Gómez, María Cecilia. El desarrollo de la voz de autor (writer's voice) en la escritura académica de los estudiantes universitarios de español como lengua heredada: aportaciones de la lingüística sistémico funcional. México: Universidad Nacional Autónoma de México. 2014.

12. Van Dijk, Teun A. La ciencia del texto. México: Paidós. 1983.

13. Brinker, Klaus. El análisis lingüístico del texto, traducción y adaptación de Guiomar Elena Ciapuscio, Berlin: E. Schmidt. 1988.

14. Charadeau Patrick. La problemática de los géneros. De la situación a la construcción textual, Signos. 2004;37(56):23-39.

15. Eggins, Suzanne, Martin, et al. El contexto con género: una perspectiva lingüística funcional. Signos. 2003;36 (54):185-205.

16. Ciapuscio, Guiomar Elena. La noción de género en la lingüística sistémico funcional y en la lingüística textual, Signos. 2015;38(57):3148.

17. Lea, Mary \& Street, Brian. Students writing in higher education. An academic literacies approach, Studies in Higher Education. 1988;23(2):157-172.

18. Arenas Cruz, María Elena. Hacia una teoría general del ensayo: construcción del texto ensayístico, Cuenca: Ediciones de la Universidad de Castilla-La Mancha. 1997.

19. Weinberg, Liliana \& Melgar, Ricardo. El ensayo. In Enciclopedia de conocimientos fundamentales I, México: UNAM and Siglo XXI. 2010.

20. Aullón de Haro, Pedro. Teoría del ensayo, Madrid: Verbum. 2013.

21. Butrym, Alexander J. Essays on the Essay; redefining the genre, Atenas: The University of Georgia Press. 1989.

22. Starobinski, Jean. ¿Es posible definir el ensayo? Cuadernos Hispanoamericanos. 1998;575: 31-40.

23. Glaudes, Pierre, (coord)). L'essai: métamorphoses d'un genre, Toulouse: Presses Universitaires du Mirail. 2002. 
24. Besa Camprubí, Carles. El ensayo en la teoría de los géneros. Castilla. Estudios de Literatura. 2006;5:101-123.

25. Lopate, Phillip. The Art of the personal essay. An anthology from the classical era to the present, Nueva York: Doubleday. 1994.

26. Alvar, Manuel. La turbada historia de la palabra "Ensayo", Alicante: Biblioteca Virtual Miguel de Cervantes. 2007.

27. Klaus, Karl H, Stuckey-French, et al. Essayists on the essay: Montaigne to our time, Iowa: University of Iowa Press. 2012.

28. Weinberg, Liliana. El ensayo en busca del sentido. Madrid: Ed. Iberoamericana, Veuvert and Universidad Nacional Autónoma de México. 2014.

29. Simón Pérez, José Rafael. Propuesta para la determinación de los tipos de textos, Sapiens. Revista Universitaria de Investigación. 2006;7(1):163-179.

30. García Córdoba, Fernando, González Méndez, et al. El ensayo: consideraciones teóricas y prácticas para su elaboración. México: Limusa. 2014.

31. Gómez de Silva, Guido. Diccionario etimológico de la lengua española México: El Colegio de México y Fondo de Cultura Económica. 2004.

32. Larousse. Diccionario ilustrado, México: Larouse. 2015.

33. Wetson, Anthony. Las claves de la argumentación. Barcelona: Ariel. 2002.

34. Ortega y Gasset, José. Estudios sobre el amor. Madrid: EDAF, 1939 1995

35. Paz, Octavio. El laberinto de la soledad. México: Fondo de Cultura Económica. 1959.

36. Reyes, Alfonso. Visión de Anáhuac, México: Universidad Nacional Autónoma de México, 1917. 2003.

37. De Beugrande, Robert \& Dressler, Wolfang. Introducción a la lingüística del texto, Barcelona: Ariel-Lingüística. 1997.

38. Eco, Umberto. Lector in fabula: la cooperación interactiva en el texto narrativo, Barcelona: Lumen. 1979.

39. Cocom Pech, Jorge Miguel. El retorno literario de las voces antiguas en América, Revista ISEES. 2010;8:111-130.
40. Paz, Octavio. Leer, comprender, interpretar en Lectura y contemplación, México: Librería del Prado. 1985.

41. Gil Hernández, Roberto. Cualquier cosa menos huérfanos. El moderno pensamiento fundacional de/sobre Canarias. Fortvnatae. 2013;24:3759

42. Moreno C, Francisco, Marthe Z, et al. Cómo escribir textos académicos según normas internacionales, Barranquilla: Ediciones Uninorte. 2010.

43. Fabre-Cols, Claudine. Réécrire à l'école et au collège: De l'analyse des brouillons à 1' écriture accompagnée, Issy-les-Moulineaux: ESF éditeur. 2002.

44. Macklin, Tialitha. Compassionate Writing Response: Using Dialogic Feedback to Encourage Student Voice in the First-Year Composition Classroom. Journal of Response to Writing. 2016;2(2):88-105.

45. Hyland, Ken. Methods and methodologies in second language writing research. System. 2016;59:116-125.

46. Bajtín, Mijail. Estética de la creación verbal. México: Siglo XXI. 1990.

47. ENP. Programa de literatura mexicana e iberoamericana. In Programas de Estudio. México: Escuela Nacional Preparatoria Universidad Nacional Autónoma de México. 1996.

48. Hidalgo-Capitán, Antonio Luis. El ensayo académico: una guía para la elaboración de ensayos académicos en ciencias sociales. Huelva: Universidad de Huelva. 2012.

49. León-Portilla, Miguel. Cantos y crónicas del México antiguo. México: Fondo de Cultura Económica. 2003.

50. Montaigne, Michel de. Ensayos, edition by de María Dolores Picazo y Almudena Montojo. Madrid: Cátedra, 1595. 2006.

51. Palapanidi, Kiriakí. La enseñanza de las estrategias compensatorias. Revista Nebrija de Lingüística Aplicada a la Enseñanza de las Lenguas. 2016;10(2).

52. RAE. Diccionario de la lengua española. Real Academia Española. Madrid: Espasa-Calpe. 2001.

53. Rojas Román, Fernando de Jesús. Recursos educativos. Guía para Elaborar un Ensayo. 2011.

54. Torre Puente, Juan Carlos. Aprender a pensar y pensar para aprender Madrid: Narcea. 1992. 